\title{
Assessing Consumers' Willingness to Buy Foreign Goods: An Integrative Modeling Approach
}

\author{
Larry L. Carter ${ }^{1} \&$ Amro A. Maher ${ }^{2}$ \\ ${ }^{1}$ Utah Valley University, Orem, Utah, USA \\ ${ }^{2}$ Qatar University, Qatar \\ Correspondence: Larry L. Carter, Marketing Department, Woodbury School of Business, Utah Valley University, \\ Orem, UT, USA. Tel: 1-840-585-999. E-mail: larry.carter@uvu.edu
}

Received: March 14, $2014 \quad$ Accepted: April 14, $2014 \quad$ Online Published: May 21, 2014

doi:10.5539/ijms.v6n3p23 URL: http://dx.doi.org/10.5539/ijms.v6n3p23

\begin{abstract}
Globalization has resulted in the proliferation of foreign goods worldwide, thus saturating consumer markets with substitutable products and increasing the competitive landscape for marketers. This study attempts to provide an empirically testable, integrative model containing the majorantecedents influencing the consumer's willingness to buy these foreign goods. A sample of 800 adults from the United States was surveyed through a consumer panelto represent the broad composition of U.S. consumers. Structural equations modeling is used to assess the fit of the proposed model and provide the explanatory strengths of each predictor while in the presence of the other primary determinants in the model. The study suggests that consumer ethnocentrism, animosity, andcounty-or-origin image affect different stages of the process used by consumers to evaluate and form attitudes toward foreign goods. These evaluations and attitudes eventually lead to purchase intention, which is indicative of the consumer's purchase behavior at a later time. The findings support the proposed relationships in this baseline model and suggest that key country-related variables differ with regards to where they exert significant influence within the baseline model. Country-of-origin image is shown to influence the evaluation and attitude formation stages, while consumer ethnocentrism and animosity affects the consumers' willingness to buy foreign goods. Market entry and promotional strategies can be utilized to control these country-related effects if the marketer is aware of their influence upon foreign product purchases.
\end{abstract}

Keywords: animosity, attitude, consumer behavior, country-of-origin, ethnocentrism, foreign products, structural equations modeling

\section{Introduction}

\subsection{Research Problem}

Firms depend heavily upon consumers' perceptions and receptivity of their products in order to survive in markets saturated with competition. Thanks to a massive rate of globalization over the past few decades, this competition is attacking the firms from all fronts, both domestic and international. New consumer markets (e.g., the BRIC nations of Brazil, Russia, India, and China) are emerging worldwide that have created strong groups of middle-class consumers with the desire and financial resources to acquire goods that go beyond the necessities (Bandyopadhyay \& Banerjee, 2002; Demir, 2013). This competitive environment is definitely advantageous to these consumers, who now has more options than ever before when making purchase decisions; however it also comes at a cost, typically in the form of information overload which may lead to 'paralysis by analysis' and the subsequent postponement of purchase. Regardless, the recent advances in information diffusion have given consumers from across the globe the necessary tools to make better purchase decisions. At the same time, these innovations are forcing firms to develop the best marketing strategies possible in order to gain the market share needed to survive and profit among its many competitors.

In light of the influx of foreign goods in most marketplaces worldwide, this study investigates the primary influences that lead to an increase in consumers' willingness to buy foreign goods. While past studies have identified key determinants affectingthe purchase intention of foreign products (e.g., Balabanis \& Diamontopoulos, 2004; Fischer \& Byron, 1997; Han, 1990; Josiassen \& Assaf, 2010; Wang, Li, Barnes, \& Ahn, 2012), an attempt to model these determinants into an integrative, testable framework has not been actively 
pursued in marketing research. Based on earlier studies within the social sciences, researchstrongly supports that individuals typically go through sequential stages of cognition, affection, and conation prior to acting on a behavior (Fishbein \& Ajzen, 1975; Mowen, 1995). Given this framework, further analysis is warranted in consumer research regarding the influence of the previously-identified key determinants upon each stage of this process.

The objective of this study is to organize these determinants into an integrative model in order to test all of the proposed relationships simultaneously. Since these determinants do not thrive alone in the marketplace, it is important to demonstrate their influences while in the presence of each other in the statistical analysis as well. Managerial applications are derived from the findings and limitations of this study are addressed.

\subsection{Literature Review}

Many researchers have previously examined the relationship between cognitive, affective, and conative influences upon a consumer's decision to purchase variousproducts and services (e.g., Li, Monroe \& Chan, 1994; Mowen, 1995; Zajonc, 1984). These studies theorize that beliefs about the goods and services (the cognition stage) are typically formulated prior to attitude formation (the affective stage) and therefore directly influence affect, which subsequently leads purchase intention (the conative stage), which is indicative of future behavior. Consumers form product beliefs through the processing of information from a variety of sources, including product exposure, advertisements, word-of-mouth communication, and possibly through hands-on experience with the product itself. With enough product information, consumers are able to develop an attitude towards the product, which is an enduring feeling about the product that is difficult to change over time with the accrual of supportive information. In consumer research, the actual behavior is a manifestation of the cognitive, affective, and conative stagesby the consumer, resulting in an action such as purchasing a product, declining to purchase, or even postponing the purchase.

A thorough literature search resulted in the reviewof 145 articles that identified potential variables influencing consumer perceptions and purchase of foreign goods. The literature search also revealed that researchers have not attempted to develop a framework that identifies the major determinants of each stage of the consumer purchase decision process. This study attempts to model the effects of primary variables upon three stages of this process: the consumers' foreign product evaluation, their attitude towards these products, and their willingness to buy the products.In developing this integrative model, the study incorporates several components designed to increase the parsimony of the framework while maintaining internal consistency and managerial applicability. The challenges of measuring actual consumer purchasesin an empirical study oftentimes lead to purchase intention variables (e.g., likelihood of future purchase, reluctance to buy, or willingness to buy) serving as suitable indicators of consumer purchase behavior (Han, 1988; Klein, Ettenson, \& Morris, 1998; Liefeld, 1993; Suh \& Kwon, 2002).

\subsection{Proposed Model}

Figure 1 illustrates the conceptual framework of the construct relationships identified and supported by the literature review. Given that this study is investigating the general perceptions of all goods from a particular country, product-specific attributes (such as brand image and price) that have been identified as determinants in previous research are not included in the framework. This model consists of the primary variables affecting the first three stages of the consumer purchase decision process. Aside from testing the robustness of the baseline framework consisting of foreign product evaluation, attitude towards the foreign product, and the consumer's willingness to buy the product, it proposes three country-related variables (i.e., animosity, consumer ethnocentrism, and country-of-origin image) as key predictors in the model. It also illustrates the dual influences of product evaluation upon both consumer attitudes towards the product and their willingness to purchase the product. Note that the solid arrowsin Figure 1 represent positive direct relationships and dashed arrows denote negative direct relationships. 


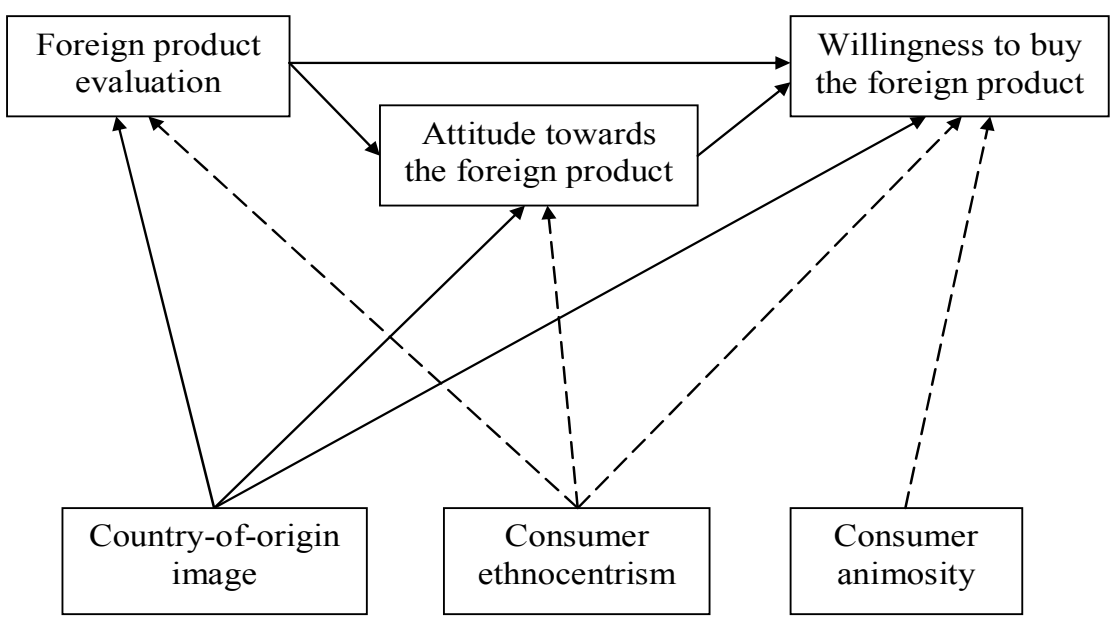

Figure 1. Conceptual model

\subsection{Hypotheses}

The causal paths within the framework represent main effects between key variables and each of the three distinct stages that serve as the theoretical foundation for this model. These relationships are based on strong support from previous research findings that pertain to the deliberation by consumers when considering a foreign product purchase (Carter, 2014). Although the influence of product beliefs upon attitudes is well documented in consumer research (e.g., Chung \& Pysarchik, 2000; Erickson, Johansson, \& Chao, 1984), the direct influence of product evaluation upon a person's willingness to buy the product is also supported within several of the studies reviewed within our literature search (e.g., Chinen, Jun, \& Hampton, 2000; Hui \& Zhou, 2002; Orbaiz \& Papadopoulos, 2003). In addition, there exists substantive support with regards to the influence of consumers' attitude towards the product upon their willingness to buy the product (e.g., Chung \& Pysarchik, 2000; Häubl, 1996; Leong et al., 2008).

Three antecedents were identified within the literature search as having profound influence while consumers are evaluating, forming attitudes toward, and intending to purchase foreign products. Given the strong associations between products and their countries-of-origin that have been established in consumer research (e.g, Brijs, Bloemer, \& Kasper, 2011; Chinen, Jun, \& Hampton, 2000; Huddleston, Good \& Stoel, 2001; Hui \& Zhou, 2002; Peris, Newman, Bigne, \& Chansarkar, 1993; Teas \& Agarwal, 2000; Uddin, Parvin, \& Rahman, 2013), country-of-origin image serves as a strong indicator for determining consumers' overall product evaluations, forming product attitudes by these consumers, and influencing their willingness to purchase the foreign product.

The second antecedent, consumer ethnocentrism has also received widespread attention within the marketing research community. Like country-of-origin image, consumer ethnocentrism is posited to have direct influence upon all three stages of the purchase decision process, albeit in the opposite direction (e.g., Klein, 2002; Maher, Clark, \& Maher, 2010; Sharma, 2011). Consumer ethnocentrism refers to the consumer's belief that buying goods from foreign countries could potentially reduce the number of domestic jobs available for their fellow citizens and create an economic downfall to their home country (Shimp \& Sharma, 1987). These feelings typically result in heavy opposition of foreign products entering their domestic market and the strong desire to seek out and purchase domestically-made goods.

The last antecedent, animosity towards a foreign country, is the most nascent variable among all of the constructs proposed in this framework, but has gained attention as an important variable in recent consumer research (e.g., Maher, Clark, \& Maher, 2010; Nijssen \& Douglas, 2004; Riefler \& Diamantopoulos, 2007). Animosity as typically defined as consumer anger that is potentially generated from various sources such as past or current military, political or economic events by the foreign country. Animosity is posited to negatively affect the consumer's purchase intention of foreign goods rather than play a significant role during the product evaluation or attitude formation stages (Klein, Ettenson, \& Morris, 1998). 
While each of these constructs has been solely assessed in previous research, this study attempts to test all of them within an integrative model to determine the relative strength of their influences. In summary, the ten hypotheses are formulated as:

H1: Product evaluation positively influences the consumer's willingness to buy the foreign product.

H2: Product evaluation positively influences the consumer's attitude towards the foreign product.

H3: Attitude towards the product positively influences the consumer's willingness to buy the foreign product.

H4: Country-of-origin image positively influences the consumer's evaluation of the foreign product.

H5: Country-of-origin image positively influences the consumer's attitude towards the foreign product.

H6: Country-of-origin image positively influences the consumer's willingness to buy the foreign product.

H7: Consumer ethnocentrism negatively influences the consumer's evaluation of the foreign product.

H8: Consumer ethnocentrism negatively influences the consumer's attitude towards the foreign product.

H9: Consumer ethnocentrism negatively influences the consumer's willingness to buy the foreign product.

H10: Consumer animosity negatively influences the consumer's willingness to buy the foreign product.

\section{Method}

\subsection{Research Design and Samples}

The survey for this study contains questions about general product image perceptions from three countries that currently vary with regards to national economic development, but trades heavily with the United States. China is considered as a newly-industrialized nation whose main competitive advantage is cheap human labor, giving it the capabilities of mass producing cheaper, lower quality products (Francis, 2012). At the other end of the American consumers' perceived quality spectrum, Japan is typically considered as a highly-developed economy that produces well-made and innovative products (Ono, Yamano, \& Takatsuki, 2012). In contrast, South Korea is typically viewed as a transitional economy that has made dramatic improvements over the past couple of decades with regards to product quality. Due to the implementation of quality improvement practices since the 1990s (Adam, Corbett, \& Rho, 1994), South Korea has been steadily increasing their country-of-origin image, thus quickly closing their quality image gap with Japan and other industrialized nations.

Several studies (e.g., Kaynak \& Cavusgil, 1983; Laroche, Papadopoulos, Heslop, \& Mourali, 2005; Nagashima, 1977) assessed a generalized or global product image from countries rather than investigate specific product categories from within the countries. These authors contend that overall evaluations of product images tend to stay in line with the country's overall image; therefore this study follows suit in assessing a global product evaluation from the three Asian countries. The constructs in this study were measured using established scales from previous research studies and were presented in the following order within the questionnaire: willingness to buy the product, attitude towards the product, product evaluation, country-of-origin image, animosity towards the country, and consumer ethnocentrism.

Initially, 131 respondents (103 adult consumers recruited from a local business and 28 university students) served as a pretest sample to ensure that these three countries vary in both country-of-origin image and felt animosity among U.S. consumers. In addition, small modifications were made to the final questionnaire design to improve both the instructions provided and the question flow. For the main study, a marketing research firm collected the data from a U.S. consumer panel, providing a total sample of 800 respondents. Each respondent provided responses about their perceptions toward and their willingness to buy products in general from China, Japan, and South Korea. The marketing research firm followed instructions to provide a sample with a high level of variance across gender, ethnicity, and geographic locations to improve the representativeness of the population. The average age of the sample is 36 years old and nearly $52 \%$ of the respondents are female. Both the racial and geographic dispersions of the sample were generally representative of the U.S. population as a whole, albeit the Hispanic population was under-represented in the sample. All of the participants received monetary compensation for completing and submitting the surveys in a timely fashion. Aselection of demographic and socio-economic characteristics for this sample is provided in Table 1. 
Table 1. Select sample characteristics $(\mathrm{N}=800)$

\begin{tabular}{llll}
\hline Demographic and socio-economic characteristics & Frequency & Percentage \\
\hline Gender: & Female & 414 & 51.8 \\
& Male & 386 & 48.2 \\
Age: & $18-24$ years & 253 & 31.6 \\
& $25-34$ years & 201 & 25.1 \\
& $35-44$ years & 109 & 13.6 \\
& $45-54$ years & 145 & 18.1 \\
& $55-64$ years & 69 & 8.6 \\
& $65+$ years & 23 & 2.9 \\
& & & 71.6 \\
& Caucasian & 753 & 16.4 \\
& African American & 131 & 4.3 \\
& Asian & 34 & 2.8 \\
& Hispanic & 22 & 3.8 \\
& Other & 30 & 1.3 \\
& No response & 10 & 14.6 \\
& & & 18.3 \\
& $<\$ 16,000$ & 118 & 33.0 \\
& $\$ 16,000-\$ 29,999$ & 146 & 10.9 \\
$\$ 30,000-\$ 74,999$ & 264 & 21.6 \\
\hline
\end{tabular}

\subsection{Measures and Data Analysis}

All measures used in this study were adapted from previous research. The majority of these measures required only minor modifications to directly address products from foreign countries. Given that this study is investigating general product images from specific countries, the items containing specific product attributes were not used with respect to the country-of-origin image scale (Pisharod \& Parameswaran, 1992). Table 2 provides a summary of the measures utilized in this study.

Table 2. Summary of measures

\begin{tabular}{|c|c|c|c|}
\hline Variable: & Previous studies: & Scale type: & \# Items: \\
\hline \multirow[t]{2}{*}{ Foreign product evaluation } & Klein, Ettenson, \& Morris, 1998 & Likert & 6 \\
\hline & Wood \& Darling, 1993 & & \\
\hline \multirow[t]{2}{*}{ Attitude towards the foreign product } & Bluebulhuber, Carter, \&Lambe 2007 & Semantic & 3 \\
\hline & Simonin\& Ruth, 1998 & differential & \\
\hline \multirow[t]{2}{*}{ Willingness to buy } & Darling \& Arnold, 1988 & Likert & 6 \\
\hline & Darling \& Wood, 1990 & & \\
\hline Country-of-origin image & Pisharod\&Parameswaran, 1992 & Likert & 30 \\
\hline \multirow[t]{2}{*}{ Consumer ethnocentrism } & Douglas \&Nijssen, 2003 & Likert & 10 \\
\hline & Netemeyer, Durvasula, \& Lichtenstein, 1991 & & \\
\hline Consumer animosity & Klein, Ettenson, \& Morris, 1998 & Likert & 9 \\
\hline
\end{tabular}

The hypotheses in this empirical model consist of one exogenous variable (willingness to buy the product) and five endogenous variables (foreign product evaluation, attitude towards the product, country-of-origin image, consumer ethnocentrism, and animosity towards the foreign country). Boththe SPSS and AMOS statistic program packages were used for the data analyses and structural equation modeling (i.e., SEM). The maximum likelihood method is used to estimate model parameters and the two-stage model analysis approach proposed by Anderson and Gerbing (1988) is used to validate both the measurement model and the structural model. The ten hypotheses are tested to support the proposed relationships within the model. 


\section{Results}

Before proceeding with the confirmatory factor analysis, the normality assumption was assessed by examining skewness and kurtosis values and internal consistency was determined by reviewing the Cronbach's Alpha for each construct (Hair, Black, Babin, \&Anderson, 2010). All observed variables expressed skewness values below \pm 2.58 and kurtosis values below \pm 1.96 and were therefore retained for further analyses. Homoscedasticity is demonstrated by a reasonable spread of variance within the bivariate scatterplots and the assumption of linearity between the dependent variable (willingness to buy) and the residuals is established through the inspection of the normal probability plots. As illustrated in Table 3, composite reliability scores were assessed across all three country models and range from .81 to .97 , demonstrating acceptable levels of internal consistency (i.e., alphas above .70) in accordance with Nunnally (1978).

Table 3. Internal consistency results

\begin{tabular}{llll}
\hline & \multicolumn{2}{l}{ Composite Reliability Alphas } & China \\
Variable: & Japan & South Korea & .81 \\
Country-of-origin image (COI) & .86 & .86 & .85 \\
Foreign product evaluation (EVAL) & .86 & .87 & .97 \\
Attitude towards the foreign product (ATT) & .97 & .96 & .87 \\
Willingness to buy the foreign product (WTB) & .84 & .86 & .81 \\
Animosity towards the foreign country (ANIM) & .83 & .86 & .97 \\
Consumer ethnocentrism (CET) & .97 & .97 & \\
\hline
\end{tabular}

\subsection{Measurement Model}

A confirmatory factor analysis is performed to validate the measurement model, resulting in acceptable model fit across all three country models. Table 4 illustrates the $\chi^{2}$, normed $\chi^{2}$, and RMSEA values to assess absolute fit, while both CFI and TLI scores are used to evaluate incremental fit.

Table 4. Fit statistics of the measurement model

\begin{tabular}{lllllll}
\hline & $\chi^{2}$ & $d f$ & $\chi^{2} / d f$ & RMSEA & CFI & TLI \\
\hline Japan & $3811.97 * * *$ & 1107 & 3.44 & .06 & .91 & .90 \\
South Korea & $3867.32^{* * *}$ & 1107 & 3.49 & .06 & .91 & .90 \\
China & $4132.02 * * *$ & 1107 & 3.73 & .06 & .90 & .89 \\
\hline
\end{tabular}

Note. $* * *$ Significant at $\mathrm{p}<.001$.

In general, all fit measures display acceptable levels of both absolute and incremental fit. The overall model $\chi^{2}$ statistics for the three country models range from 3811.97 to 4132.02 and are statistically significant at the .001 level. The alternative global fit measure (i.e., the normed $\chi^{2}$ ) ranges in value from 3.44 to 3.73 , and indicates acceptable fit according to the standards put forth by Hair, Black, Babin, and Anderson (2010). The RMSEA fit assessment is also acceptable with values ranging from .055 to .058 and furthermore, it approaches values that indicate an excellent degree of model fit (Kline, Ettenson, \& Morris, 1998). As for the incremental fit measures, the CFI index for the Japanese, South Korean and Chinese models are .90, .91, and .91, respectively. Given that CFI values exceeding .90 indicate adequate model fit (Bentler, 1990), all three models meet this criteria and demonstrate acceptable fit. Similar results are found for the TLI incremental fit statistic (i.e., the non-normed fit index). While the TLI values for the Japanese and South Korean models surpass the minimum score of .90 for adequate fit (Bentler \& Bonett, 1980), the Chinese model is at the threshold of acceptable fit with a value of .89.

Two assessments, specifically the average variance extracted (AVE) and construct reliability, are conducted to provide evidence of convergent validity. An inspection of the AVE scores indicates that nearly all loadings across the three models exceed the .50 threshold and that each construct surpassed this threshold within at least one or more country models, thus indicating an acceptable degree of convergent validity. With regards to the construct reliability analysis, all constructs exceed the .70 cut-off value, thus providing substantial evidence of convergent validity as well. Table 5 provides both the average variance extracted as well as the construct reliability scores for all three country models. 
Table 5. Average variance extracted and construct reliability scores

\begin{tabular}{lllllll}
\hline & Japan & \multicolumn{3}{c}{ South Korea } & China \\
& AVE & CR & AVE & CR & AVE & CR \\
\hline ATT & $.92^{*}$ & $.94^{* *}$ & $.89^{*}$ & $.91^{* *}$ & $.93^{*}$ & $.93^{* *}$ \\
EVAL & $.53^{*}$ & $.74^{* *}$ & $.54^{*}$ & $.74^{* *}$ & $.50^{*}$ & $.67^{* *}$ \\
COI & $.72^{*}$ & $.91^{* *}$ & $.69^{*}$ & $.90^{* *}$ & $.63^{*}$ & $.85^{* *}$ \\
ANIM & .47 & $.72^{* *}$ & .49 & $.75^{* *}$ & $.54^{*}$ & $.74^{* *}$ \\
CET & $.63^{*}$ & $.89^{* *}$ & $.63^{*}$ & $.89^{* *}$ & $.63^{*}$ & $.89^{* *}$ \\
WTB & $.53^{*}$ & $.66^{* *}$ & $.55^{*}$ & $.67^{* *}$ & $.55^{*}$ & $.62^{* *}$ \\
\hline
\end{tabular}

Note. $*$ AVE value $>.50, * * \mathrm{CR}$ value $>.60$.

Researchers typically test for discriminant validity by comparing squared values of the estimated correlations between the constructs and the average variance extracted (i.e., AVE) from each construct. If the variable's AVE value is higher than the square of the estimated correlation between itself and another variable, then there is evidence to support an acceptable degree of discriminant validity between these variables. The measurement model was re-specified by setting the variances of all six variables to a value of 1.0. Each of the path parameters between the constructs and their indicators were not set and therefore were estimated. Table 6 provides each country's matrix of the squared values of the estimated correlations between each variable pair and the AVE scores along the diagonal of each matrix.

Table 6. Construct correlations matrices

\begin{tabular}{|c|c|c|c|c|c|c|c|c|c|c|c|c|c|c|c|c|c|c|}
\hline & \multicolumn{6}{|c|}{ Japan } & \multicolumn{6}{|c|}{ South Korea } & \multicolumn{6}{|c|}{ China } \\
\hline & 1. & 2. & 3. & 4. & 5. & 6. & 1. & 2. & 3. & 4. & 5. & 6. & 1. & 2. & 3. & 4. & 5. & 6. \\
\hline 1.ANIM & .47 & & & & & & .49 & & & & & & .54 & & & & & \\
\hline 2.ATT & .30 & .92 & & & & & .25 & .89 & & & & & .33 & .93 & & & & \\
\hline 3.CET & .21 & .21 & .63 & & & & .35 & .13 & .63 & & & & .30 & .07 & .63 & & & \\
\hline 4.COI & .55 & .48 & .18 & .72 & & & .60 & .35 & .21 & .69 & & & .66 & .35 & .22 & .63 & & \\
\hline 5.EVAL & .29 & .59 & .15 & .48 & .53 & & .21 & .52 & .10 & .40 & .54 & & .25 & .60 & .04 & .43 & .50 & \\
\hline 6.WTB & .39 & .43 & .31 & .33 & .34 & .53 & .37 & .34 & .28 & .30 & .31 & .55 & .42 & .46 & .22 & .41 & .36 & .55 \\
\hline
\end{tabular}

The overall results from comparing AVE estimates to their corresponding inter-construct squared correlation estimates indicate discriminant validity among these variables. Despite these favorable outcomes, there are two potential issues that are worth noting from the analysis. The squared correlation estimates between the attitude and evaluation constructs are higher than the average variances extracted for evaluation across two models (Japan and China), but are lower than the AVE score for the attitude variable across all three models. A second pair of constructs, country-of-origin image and animosity, also produced mixed results. While the AVE values for animosity are lower than the corresponding squared correlation estimates for all three models, the AVE estimate for country-of-origin image is higher than these estimates for the Japanese and South Korean models.

\subsection{Structural Model and Hypotheses Testing}

A structural model is constructed for each of the three Asian countries in order to test the ten hypothesized relationships among the six constructs of interest. The fit statistics are illustrated in Table 7 and indicate good fit across all three country models.

Table 7. Fit statistics of the structural model

\begin{tabular}{lllllll}
\hline & $\chi^{2}$ & $d f$ & $\chi^{2} / d f$ & RMSEA & CFI & TLI \\
\hline Japan & $3812.46^{* * *}$ & 1109 & 3.44 & .06 & .91 & .90 \\
South Korea & $3871.73^{* * *}$ & 1109 & 3.49 & .06 & .91 & .90 \\
China & $4150.59^{* * *}$ & 1109 & 3.74 & .06 & .90 & .89 \\
\hline
\end{tabular}

Note. *** Significant at $\mathrm{p}<.001$. 
The $\chi^{2}$ statistics for the three country models are statistically significant at the .001 level, ranging in value from 3812.46 to 4150.59 . The normed $\chi^{2}$ statistics range from 3.44 to 3.74 and provides additional evidence of acceptable absolute fit. The RMSEA fit statistic is also significant with a consistent value of .06 across all three country models, indicating an acceptable degree of model fit. As for the incremental fit measures, the CFI index is valued at .90 for the Chinese model and .91 for both the South Korean and Japanese models. Given that CFI values exceeding .90 indicate adequate model fit, the Japanese and South Korean models meet this criteria and the Chinese model is at the threshold of acceptable fit. Similar results are found for the TLI incremental fit statistic. While the TLI values for the Japanese and South Korean models surpass the minimum score of .90 for adequate fit, the Chinese model falls just short of this cut-off value at .89 .

Table 8 illustrates the results of the hypotheses testing and includes the standardized estimates of the proposed paths for all three Asian country models. The data fully supports five of the ten hypothesized relationships, while four relationships receive partial support. Also based on the data analysis, only one theorized relationship has no support of statistical significance.

Table 8. Standardized coefficients for the structural model

\begin{tabular}{|c|c|c|c|c|}
\hline & Japan & South Korea & China & Support \\
\hline $\mathrm{H} 1: \mathrm{EVAL} \rightarrow \mathrm{WTB}$ & $.09^{*}$ & $.12 * * *$ & .08 & Partial \\
\hline $\mathrm{H} 2: \mathrm{EVAL} \rightarrow \mathrm{ATT}$ & $.68 * * *$ & $.70 * * *$ & $.75 * * *$ & Yes \\
\hline H3: ATT $\rightarrow$ WTB & $.21 * * *$ & $.11^{* * *}$ & $.22 * * *$ & Yes \\
\hline H4: COI $\rightarrow$ EVAL & $.85^{* * *}$ & $.68^{* * *}$ & $.96^{* * *}$ & Yes \\
\hline $\mathrm{H} 5: \mathrm{COI} \rightarrow \mathrm{ATT}$ & $.24 * * *$ & $.28 * * *$ & $.38 * * *$ & Yes \\
\hline H6: COI $\rightarrow$ WTB & .01 & -.06 & .14 & No \\
\hline $\mathrm{H} 7: \mathrm{CET} \rightarrow \mathrm{EVAL}$ & $-.08^{*}$ & -.03 & $-.12 * *$ & Partial \\
\hline H8: CET $\rightarrow$ ATT & $-.18^{* * *}$ & -.09 & -.03 & Partial \\
\hline H9: $\mathrm{CET} \rightarrow$ WTB & $-.15^{* * *}$ & $-.10 * * *$ & $-.14 * * *$ & Yes \\
\hline H10: ANIM $\rightarrow$ WTB & $-.23 * * *$ & $-.21 * * *$ & -.16 & Partial \\
\hline
\end{tabular}

Note. $*$ Significant at $\mathrm{p}<.05, * *$ Significant at $\mathrm{p}<.01, * * *$ Significant at $\mathrm{p}<.001$.

The positive coefficient estimates for the path from product evaluation to willingness to buy the product are significant for the Japanese and South Korean models at $\beta=.09(p<.05)$ and $\beta=.12(p<.001)$, respectively. However, the Chinese model does not show statistical significance for this path $(\beta=.08, p=.06)$ and partially supports $\mathrm{H} 1 . \mathrm{H} 2$ theorizes that product evaluation influences consumer attitude towards the product. All three models support this hypothesis with positive estimate values of $\beta=.68(p<.001)$ for Japan, $\beta=.70(p<.001)$ for South Korea, and $\beta=.75(p<.001)$ for China.

Similarly, the positive relationship between consumer attitude and willingness to buy the product is significant at the $p<.001$ level for all three models (Japan: $\beta=.21$, South Korea: $\beta=.11$, and China: $\beta=.22$ ) and supports H3. The next two hypotheses state that country-of-origin image positively influences product evaluation (H4) as well as consumer attitude towards the foreign product (H5). Regression estimates for H4 support the hypothesis across all three models with values of $\beta=.85(p<.001)$ for Japan, $\beta=.68(p<.001)$ for South Korea, and $\beta=.96(p<.001)$ for China. The estimates were also statistically significant at the $p<.001$ level for all three models (Japan: $\beta=.24$, South Korea: $\beta=.28$, and China: $\beta=.38$ ) and fully support $\mathrm{H} 5$.

Contrary to expectations, the analysis reveals no positive effect of country-of-origin image upon the consumer's willingness to buy. In fact, $\mathrm{H} 6$ is the only hypothesis in this study that receives no statistical support across all three country models. The coefficient estimates are $\beta=.01(p=.12)$ for Japan, $\beta=-.06(p=.30)$ for South Korea, and $\beta=.14(p=.24)$ for China. The Japanese and Chinese models support the negative influence of consumer ethnocentrism upon product evaluation (i.e., H7) with coefficient estimate of $\beta=-.08(p<.05)$ and $\beta=-.12(p<.01)$, respectively; however the South Korean model does not support this hypothesis $(\beta=-.03, p=.38)$. 
H8 proposes that consumer ethnocentrism negatively influences consumer attitude and is also partially supported The Japanese and Korean models provide statistical significance with estimated path values of $\beta=-.18(p<.001)$ and $\beta=-.09(p<.01)$, respectively; however the Chinese model does not show statistical significance for the path ( $\beta=-.03, p=.43$ ), resulting in partial support for H8. All three country models support the hypothesized negative effect of consumer ethnocentrism upon willingness to buy foreign products (i.e., $\mathrm{H}_{9}$ ) at the $p<.001$ level (Japan: $\beta=-.15$, South Korea: $\beta=-.10$, and China: $\beta=-.14$ ).

Finally, the last hypothesis theorizes that animosity towards a foreign country negatively influences the consumer's willingness to buy products from that country. The Japanese $(\beta=-.23)$ and South Korean $(\beta=-.21)$ models support this hypothesis at the $p<.001$ level, but the South Korean model $(\beta=-.16, p=.11)$ rejects it, thus H10 only receives partial support from the analysis.

\section{Discussion}

The primary contribution of this study is to test the proposed effects of main determinants of foreign product purchase within a comprehensive framework. While both country-of-origin image and consumer ethnocentrism influence product evaluations as well as consumer attitudes toward foreign goods, the nature of their relationships are vastly different. A positive increase in country-of-origin image tends to foster more positive evaluations and attitudes toward the foreign product, while consumer ethnocentrism tends to impact these evaluations and attitudes in the negative direction. Therefore, consumers who are highly ethnocentric will more likely evaluate foreign products negatively as well as form negative attitudes toward the products. Given that only partial support was found for these relationships, it may stand to reason that the differences between countries themselves may play a role in attenuating these effects. Thus it is plausible that the more familiar a consumer is with a country-of-origin and its products, the less likely she will rely on her ethnocentric tendencies to evaluate and form attitudes towards its goods.

Another interesting set of findings from this study pertains to the proposed relationships impacting the outcome variable, willingness to buy. Product evaluation, attitude towards the product, and country-of-origin image are theorized to positively influence willingness to buy, while both consumer ethnocentrism and animosity are proposed to have negative influences upon the outcome variable. While nearly all of these relationships were either fully or partially supported by the three models of analysis, country-of-origin image does not significantly influence a consumer's willingness to purchase foreign products. This finding suggests that the consumer places more reliance on country-of-origin information during the early stages of developing beliefs and attitudes about the product of interest. Consumers combine country information with other product information in order to formulate their impression of the product during the information search and alternative evaluation stages of the buying decision process.

In contrast, the study supports the idea that consumer ethnocentrism has a negative influence at the willingness-to-buy stage of the process; however its effects upon product evaluation and attitude formation are partially supported. These findings indicate that consumers may develop positive evaluations of and attitudes toward foreign products, but due to their high levels of consumer ethnocentrism, they would never intend to purchase them. The consumer's animosity towards the foreign country is also found to have a negative influence upon her willingness to buy products from that country; however it was only partially supported by the Japanese and South Korean models. This result suggests that, while not directly measured in this study, animosity resulting from previous war conflicts with these two nations may be reflected within the general animosity item scores and should be evaluated in subsequent research.

Armed with this information, marketers can create more effective strategies to increase foreign consumers' overall receptivity and subsequent purchase of their products. If products are being imported by countries that elicit negative reactions by the consumers, those marketers should consider ways to negate or dissipate their negative country-of-origin image. For example, the practice of foreign branding is often used to alter consumers'product perceptions by labeling a product with a foreign-sounding brand name. In terms of product distribution, the foreign marketer may consider a joint venture or brand alliance, whereby they partner with a local firm to serve in the forefront with hopes that the consumers will perceive the product as being more 'local.' If the manufacturer is fully committed to serving the foreign market, they should consider building a plant within the foreign country, employ the foreign workers, and in time, perhaps be viewed more as a local firm than a foreign company by consumers.

The following limitations of this study provide opportunities to further this research with more robust analytical procedures and expansion beyond the study of consumer goods. It is also important to note that, since previous studies typically assessed influences upon one or two stages of consumer perception and purchase of foreign 
products, multicollinearity is likely to become an issue within a model with an extensive number of influences being evaluated. To some extent, a confirmatory factor analysis conducted at the early stages of analysis may help alleviate this problem. Secondly, the study of consumer animosity is still in its infancy and requires additional scale development and operational refinement within marketing research. Thirdly, the possible influence of country familiarity was mentioned earlier in the discussion and warrants further investigation concerning its effect upon the country-related variables within the framework. Finally, this empirical model should be extended to buying situations other than the purchase of foreign goods to include buying decisions toward services, tourism, and possibly business-related purchases.

\section{References}

Adam Jr., E. E., Corbett, L. M., \& Rho, B. H. (1994). Quality improvement practices in Korea, New Zealand and the USA. International Journal of Quality \& Reliability Management, 11(7), 6-18.

Anderson, J. C., \& Gerbing, D. W. (1988). Structural equation modeling in practice: a review and recommended two-step approach. Psychological Bulletin, 10, 411-423. http://dx.doi.org/10.1037/0033-2909.103.3.411

Balabanis, G., \& Diamantopoulos, A. (2004). Domestic country bias, country-of-origin effects, and consumer ethnocentrism: a multidimensional unfolding approach. Journal of the Academy of Marketing Science, 32(1), 80-95. http://dx.doi.org/10.1177/0092070303257644

Bandyopadhyay, S., \& Banerjee, B. (2002). A country of origin analysis of foreign products by Indian consumers. Journal of International Consumer Marketing, 15(2), 85-109. http://dx.doi.org/10.1300/J046v15n02_06

Bentler, P. M. (1990). Comparative fit indexes in structural models. Psychological Bulletin, 107(2), 238-246. http://dx.doi.org/10.1037/0033-2909.107.2.238

Bentler, P. M., \& Bonett, D. G. (1980). Significance tests and goodness of fit in the analysis of covariance structures. Psychological Bulletin, 88(3), 588-606. http://dx.doi.org/10.1037/0033-2909.88.3.588

Bluemelhuber, C., Carter, L. L., \&Lambe, C. J. (2007). Extending the view of brand alliance effects: an integrative examination of the role of country of origin. International Marketing Review, 24(4), 427-443. http://dx.doi.org/10.1108/02651330710761008

Brijs, K., Bloemer, J., \& Kasper, H. (2011). Country-image discourse model: unraveling meaning, structure, and function of country images. Journal of Business Research, 64, 1259-1269. http://dx.doi.org/10.1016/j.jbusres.2011.01.017

Carter, L. L. (2014). An analysis of country-related determinants influencing consumer receptivity of foreign products. International Business Research, 7(6), in press.

Chinen, K., Jun, M., \& Hampton, G. M. (2000). Product quality, market presence, and buying behavior: aggregate images of foreign products in the U.S. Multinational Business Review, Spring, 29-38.

Chung, J. E., \& Pysarchik, D. T. (2000). A model of behavioral intention to buy domestic versus imported products in a Confucian culture. Marketing Intelligence \& Planning, 18(5), 281-291. http://dx.doi.org/10.1108/02634500010343982

Darling, J. R., \& Arnold, D. R. (1988). Foreign consumers' perspective of the products and marketing practices of the United States versus selected European countries. Journal of Business Research, 17(3), 237-248. http://dx.doi.org/10.1057/palgrave.jibs.8490827

Darling, J. R., \& Wood, V. R. (1990). A longitudinal study comparing perceptions of U.S. and Japanese consumer products in a third neutral country: Finland 1975 to 1985. Journal of International Business Studies, 21(3), 427-450. http://dx.doi.org/10.1057/palgrave.jibs.8490827

Demir, O. (2013). Is Turkey far from BRIC countries? International Journal of Business and Social Science, 4(5), 136-141.

Douglas, S. P., \& Nijssen, E. J. (2003). On the use of 'borrowed' scales in cross-national research: a cautionary note. International Marketing Review, 20(6), 621-642. http://dx.doi.org/10.1108/02651330310505222

Fischer, W. C., \& Byron, P. (1997). Buy Australian made. Journal of Consumer Policy, 20, 89-97. http://dx.doi.org/10.1023/A:1006856704983

Fishbein, M., \& Ajzen, I. (1975). Belief, attitude, intention, and behavior: an introduction to theory and research. Reading, MA: Addison-Wesley. 
Francis, D. (2012). Understanding China's Impact on American Consumers. US News \& World Report. Retrieved from $\mathrm{http}: / /$ news.yahoo.com/understanding-chinas-impact-american-consumers-201901902.html?soc_src=copy

Hair Jr., J. F., Black, W. C., Babin, B. J., \& Anderson, R. E. (2010). Multivariate data analysis (7th ed.). Upper Saddle River, NJ: Pearson Education.

Han, C. M. (1988). The role of consumer patriotism in the choice of domestic versus foreign products. Journal of Advertising Research, 28, 25-31.

Han, C. M. (1990). Testing the role of country image in consumer choice behavior. European Journal of Marketing, 24(6), 24-40. http://dx.doi.org/10.1108/EUM0000000000609

Häubl, G. (1996). A cross-national investigation of the effects of country of origin and brand name on the evaluation of a new car. International Marketing Review, 13(5), 76-97. http://dx.doi.org/10.1108/02651339610131405

Huddleston, P., Good, L. K., \& Stoel, L. (2001). Consumer ethnocentrism, product necessity and Polish consumers' perceptions of quality. International Journal of Retail \& Distribution Management, 29(5), 236-246. http://dx.doi.org/10.1108/09590550110390896

Hui, M. K., \& Zhou, L. (2002). Linking product evaluations and purchase intention for country-of-origin effects. Journal of Global Marketing, 15(3/4), 95-116. http://dx.doi.org/10.1300/J042v15n03_05

Josiassen, A., \& Assaf, A. G. (2010). Country-of-origin contingencies: their joint influence on consumer behaviour. Asia Pacific Journal of Marketing and Logistics, 22(3), 294-313. http://dx.doi.org/10.1108/13555851011062241

Kaynak, E., \& Cavusgil, S. T. (1983). Consumer attitudes toward products of foreign origin: do they vary across product classes? International Journal of Advertising, 2, 147-157.

Klein, J. G. (2002). Us versus them, or us versus everyone?Delineating consumer aversion to foreign goods. Journal of International Business Studies, 33(2), 345-363. http://dx.doi.org/10.1057/palgrave.jibs.8491020

Klein, J. G., Ettenson, R. E., \& Morris, M. D. (1998). The animosity model of foreign product purchase: an empirical test on the People's Republic of China. Journal of Marketing, 62(1), 89-100. http://dx.doi.org/10.2307/1251805

Laroche, M., Papadopoulos, N., Heslop, L. A., \&Mourali, M. (2005). The influence of country image structure on consumer evaluations of foreign products. International Marketing Review, 22(1), 96-115. http://dx.doi.org/10.1108/02651330510581190

Leong, S. W., Cote, J. A., Ang, S. H., Tan, S. J., Jung, K., Kau, A. K., \& Pornpitakpan, C. (2008). Understanding consumer animosity in an international crisis: nature, antecedents, and consequences. Journal of International Business Studies, 39, 996-1009. http://dx.doi.org/10.1057/palgrave.jibs.8400392

Li, W. K., Monroe, K. B., \& Chan, D. K. S. (1994). The effects of country of origin, brand, and price information: a cognitive-affective model of buying intentions. In C. T. Allen \& D. R. John (Eds.), NA Advances in Consumer Research (Vol. 21, pp. 449-457). Provo, UT.

Liefeld, J. P. (1993). Consumer use of country-of-origin information in product evaluations: evidence from experiments. In N. Papadopoulos \& L. A. Heslop (Eds.), Product and Country Images: Impact and Role in International Marketing (pp. 117-156). New York, NY: The Haworth Press, Inc.

Maher, A. A., Clark, P., \& Maher, A. (2010). International consumer admiration and the persistence of animosity. Journal of Consumer Marketing, 27(5), 414-424. http://dx.doi.org/10.1108/07363761011063312

Mowen, J. C. (1995). Consumer behavior (4th ed.). Englewood Cliffs, NJ: Prentice Hall.

Nagashima, A. (1977). A comparative 'made in' product image survey among Japanese businessmen. Journal of Marketing, 41(3), 95-100. http://dx.doi.org/10.2307/1250943

Netemeyer, R. G., Durvasula, S., \& Lichtenstein, D. R. (1991). A cross-national assessment of the reliability and validity of the CETSCALE. Journal of Marketing Research, 28(3), 320-327. http://dx.doi.org/10.2307/3172867

Nijssen, E. J., \& Douglas, S. P. (2004). Examining the animosity model in a country with a high level of foreign trade. International Journal of Research in Marketing, 21(1), 23-38. http://dx.doi.org/10.1016/j.ijresmar.2003.05.001 
Nunnally, J. C. (1978). Psychometric theory (2nd ed.). New York, NY: McGraw-Hill.

Ono, Y., Yamano, M., \& Takatsuki, K. (2012). Report on image of products made in Japan in 14 Asian cities. Global HABIT $\quad-\quad$ Hakuhodo. $\quad$ Retrieved from http://japan-product.com/japanese-products-has-excellent-quality/

Orbaiz, L. V., \& Papadopoulos, N. (2003). Toward a model of consumer receptivity of foreign and domestic products. Journal of International Consumer Marketing, 15(3), 101-126. http://dx.doi.org/10.1300/J046v15n03_06

Peris, S. M., Newman, K., Bigne, E., \& Chansarkar, B. (1993). Aspects of Anglo-Spanish perceptions and product preferences arising from 'country of origin' image. International Journal of Advertising, 12, $131-142$.

Pisharod, R. M., \& Parameswaran, R. (1992). Confirmatory factor analysis of a country-of-origin scale: initial results. In J. F. Sherry, Jr. \& B. Sternthal (Eds.), NA - Advances in Consumer Research (Vol. 19, pp. 706-714). Provo, UT.

Riefler, P., \& Diamantopoulos, A. (2007). Consumer animosity: a literature review and a reconsideration of its $\begin{array}{llll}\text { measurement. International } & \text { Marketing }\end{array}$ http://dx.doi.org/10.1108/02651330710727204

Sharma, P. (2011). Country of origin effects in developed and emerging markets: exploring the contrasting roles of materialism and value consciousness. Journal of International Business Studies, 42, 285-306. http://dx.doi.org/10.1057/jibs.2010.16

Shimp, T. A., \& Sharma, S. (1987). Consumer ethnocentrism: construction and validation of the CETSCALE. Journal of Marketing Research, 24, 280-289. http://dx.doi.org/10.2307/3151638

Simonin, B. L., \& Ruth, J. A. (1998). Is a company known by the company it keeps? Assessing the spillover effects of brand alliances on consumer brand attitudes. Journal of Marketing Research, 35(1), 30-42. http://dx.doi.org/10.2307/3151928

Suh, T., \& Kwon, I. G. (2002). Globalization and reluctant buyers. International Marketing Review, 19(6), 663-680. http://dx.doi.org/10.1108/02651330210451962

Teas, R. K., \& Agarwal, S. (2000). The effects of extrinsic product cues on consumers' perceptions of quality, sacrifice, and value. Journal of the Academy of Marketing Science, 28(2), 278-290. http://dx.doi.org/10.1177/0092070300282008

Uddin, J., Parvin, S., \& Rahman, M. L. (2013). Factors influencing importance of country of brand and country of manufacturing in consumer product evaluation. International Journal of Business and Management, 8(4), 65-74. http://dx.doi.org/10.5539/ijbm.v8n4p65

Wang, C. L., Li, D., Barnes, B. R., \& Ahn, J. (2012). Country image, product image and consumer purchase intention: evidence from an emerging economy. International Business Review, 21, 1041-1051. http://dx.doi.org/10.1016/j.ibusrev.2011.11.010

Wood, V. R., \& Darling, J. R. (1993). The marketing challenges of the newly independent republics: product competitiveness in global markets. International Marketing Review, 1(1), 77-102.

Zajonc, R. B. (1984). On the primacy of affect. American Psychologist, 39(2), 117-123. http://dx.doi.org/10.1037/0003-066X.39.2.117

\section{Copyrights}

Copyright for this article is retained by the author(s), with first publication rights granted to the journal.

This is an open-access article distributed under the terms and conditions of the Creative Commons Attribution license (http://creativecommons.org/licenses/by/3.0/). 